\title{
Phylogeography and genetic differentiation along the distributional range of the orchid Epidendrum fulgens: a Neotropical coastal species not restricted to glacial refugia
}

Fábio Pinheiro ${ }^{1,2 \star}$, Fábio de Barros ${ }^{1}$, Clarisse Palma-Silva ${ }^{1}$, Michael F. Fay ${ }^{3}$, Christian Lexer ${ }^{4}$ and Salvatore Cozzolino ${ }^{5}$

${ }^{1}$ Instituto de Botânica, Avenida Miguel Estéfano 3687, 04301-012, São Paulo, SP, Brazil, ${ }^{2}$ Departamento de Botânica, Instituto de Biociências, Universidade de São Paulo, 05508-900, São Paulo, SP, Brazil, ${ }^{3} J o d r e l l$ Laboratory, Royal Botanic Gardens Kew, Richmond TW9 3DS, UK, ${ }^{4}$ Department of Biology, Unit of Ecology and Evolution, University of Fribourg, CH-1700, Fribourg, Switzerland, ${ }^{5}$ Dipartimento di Biologia Strutturale e Funzionale, Complesso Universitario di Monte S. Ângelo, Università degli Studi di Napoli Federico II, 80100, Napoli, Italy
*Correspondence: Fábio Pinheiro, Instituto de Botânica, Avenida Miguel Estéfano 3687, 04301012, São Paulo, SP, Brazil.

E-mail: biopinheiro@yahoo.com.br

\begin{abstract}
Aim Phylogeographical studies in the Brazilian Atlantic Forest (BAF) have mostly included species associated with forest habitats, whereas taxa associated with grassland and sand-dune plant communities have so far been largely overlooked. This study examines the phylogeography of the orchid Epidendrum fulgens, which occurs on coastal sand dunes and granitic outcrops, in order to identify major genetic divergences or disjunctions across the range of the species and to investigate the genetic signatures of past range contractions and expansions.

Location Southern and south-eastern seashore vegetation along the BAF biome, and granitic and arenitic outcrops that occur in the subtropical grassland plant communities located south of the BAF.

Methods Nine nuclear and four plastid microsatellite loci were used to genotype 424 individuals from 16 populations across the distributional range of E. fulgens. For both sets of markers, we estimated genetic diversity and population differentiation, testing for a north-south gradient of genetic diversity. The plastid haplotype network and a Bayesian assignment analysis of nuclear markers were used to infer population structure. Past demographic changes were investigated using a coalescence approach.
\end{abstract}

Results A deep disjunction was found between northern populations within the BAF and southern populations outside the BAF that occur on granitic and arenitic outcrops. Recent demographic reductions were detected in northern populations on coastal sands. Such demographic changes were not expected for those populations, as previous studies with forest species had found evidence of population expansion in the same areas. Higher genetic diversity was found in southern populations on granite, in contrast to patterns observed in previous studies of forest species.

Main conclusions The results are consistent with the long-term persistence of E. fulgens. Bottlenecks were detected in populations from areas where population expansion events have been detected in other plant (and animal) species, suggesting that forest expansion after the Last Glacial Maximum played a role in the population fragmentation and decrease in genetic diversity in E. fulgens. A substantial genetic division in E. fulgens corresponds to the 'Portal de Torres', a region that demarcates the northern limits of subtropical grassland plant communities and the southern limits of the BAF. 


\section{Keywords}

Brazilian Atlantic Forest, Epidendrum, gene flow, genetic structure, microsatellites, Orchidaceae, phylogeography.

\section{INTRODUCTION}

The identification of historical demographic events and inference of population dynamics following the Last Glacial Maximum (LGM) are important for understanding the distribution of organismal diversity today (e.g. Hewitt, 1996). Because genetic signatures of population retraction and expansion depend on the geographical context, tests of demographic scenarios based on molecular markers have contributed greatly to current knowledge of biogeography (Diniz-Filho et al., 2008). One of the main goals of phylogeographical studies is the identification of historically stable areas or refugia, where populations of many taxa survived during glacial periods (Carnaval et al., 2009). Range contractions and fragmentation events have left genetic signatures in populations from refugial areas that are different from those in populations from re-colonized regions (Widmer \& Lexer, 2001).

In South America, refugia have primarily been identified for species associated with forest environments, mainly because most phylogeographical studies have focused on organisms from core rain forest habitats, including both plants (Salgueiro et al., 2004; Palma-Silva et al., 2009; Ribeiro et al., 2011) and animals (Costa, 2003; Cabanne et al., 2007; Carnaval et al., 2009; Thomé et al., 2010). Using organisms not associated with forest habitats, a growing number of studies have shown that these species did not undergo dramatic range fragmentation in separate refugia during the LGM. Rather, species associated with grasslands (Jakob et al., 2009; Cosacov et al., 2010) and sand dunes (King et al., 2009) are likely to have persisted in interconnected populations across most of their current distribution. Indeed, some species experienced population fragmentation after the LGM as a result of the expansion of forest elements (Ledru et al., 2007; Antonelli et al., 2010). This scenario suggests that a significant component of the evolutionary history of species not associated with forest habitats has been largely overlooked (Jakob et al., 2009; King et al., 2009; Cosacov et al., 2010).

The Brazilian Atlantic Forest (BAF) is a biome of particular interest as it is a global biodiversity hotspot with approximately 20,000 plant species, corresponding to a considerable proportion of the South American biodiversity (Myers et al., 2000). It is a mosaic of several plant communities, composed of the core BAF and communities at the periphery of the forests, such as swamp forests, inselberg vegetation and open scrub vegetation on the sandy coastal plains known as restinga (reviewed in Scarano, 2002). Pleistocene climatic oscillations had an impact on all plant communities within the BAF (Behling, 2002), and vegetation and climate reconstructions based on pollen analysis provide strong evidence for forest contraction during the LGM (20-18 ka), with a concomitant expansion of grassland elements, mainly in southern and south-eastern Brazil (Behling \& Negrelle, 2001; Behling, 2002). Recent phylogeographical studies of BAF taxa (Cabanne et al., 2007; Ledru et al., 2007; Carnaval et al., 2009; Palma-Silva et al., 2009; Ribeiro et al., 2011) also confirm demographic changes consistent with responses to Pleistocene forest contractions and subsequent advances, after the LGM, into southern areas of the biome. In South America there have been few phylogeographical studies of taxa not associated with humid forest habitats, for example species from grasslands or sand dunes (but see Jakob et al., 2009; Cosacov et al., 2010), and the impact of the LGM on such Neotropical plant communities is yet to be fully explored.

In most angiosperms, plastid DNA is inherited maternally (Ennos, 1994; Petit et al., 2005) and therefore provides a seedspecific marker, as used for analyses of orchids by Bateman et al. (2008), Fay et al. (2009) and Micheneau et al. (2010). In species in which seed flow is lower than pollen flow, it is predicted that the plastid genome will be highly structured when compared with nuclear genes (Petit et al., 2005). Moreover, comparison with biparentally inherited nuclear markers has shed light on the relative importance of pollenand seed-mediated gene flow in the structure of plant populations (Petit et al., 2005; Duminil et al., 2007). The distribution of genetic diversity in the nuclear and plastid genomes can be used to infer demographic processes in populations of plants. Natural history and empirical studies of many outcrossing plant species indicate that pollen movement is often the predominant form of gene flow (reviewed in Duminil et al., 2007), but little is known about the dispersal abilities of species occupying unstable habitats, the demography of which resembles metapopulation models. When local demes undergo frequent extinction and recolonization events, as in the LGM, seed movement into empty patches of favourable habitat is the basic mechanism for the foundation of new subpopulations (Duminil et al., 2007). The combined use of plastid and nuclear markers, in a phylogeographical context, can enhance the power to detect historical demographic fluctuations and help to disentangle the effects of pollen versus seed flow in shaping current population structure (King et al., 2009; Palma-Silva et al., 2009).

Epidendrum L. is the largest genus of Orchidaceae in the Neotropics, with about 1500 species distributed from the south-eastern United States to northern Argentina (Hágsater \& Soto-Arenas, 2005). The genus contains many species with a wide distribution and high morphological diversity (Hágsater \& Soto-Arenas, 2005). Epidendrum fulgens Brongn. is a 
perennial terrestrial that occurs in the south-eastern region of the BAF and further south outside the BAF. This orchid grows in sand-dune fields and meadows (see Appendices S1 and S2 in Supporting Information), in the herbaceous and shrubby vegetation called restinga, on well-drained, post-beach Holocene sandy deposits (Scarano, 2002). In the southern part of its distribution, E. fulgens also occurs on granite-based bedrock and arenitic outcrops in the 'Depressão Central' physiographic region. Epidendrum fulgens is pollinated by butterflies, following a model of pollination by deceit, there being no reward (nectar) for the pollinators (Fuhro, 2006; Moreira et al., 2008). The species is self-compatible, but pollinators are necessary for pollen transfer (Fuhro, 2006).

By using a species (E. fulgens) not associated with forest habitats as our model organism, we attempt to test for the existence of phylogeographical patterns different from those found in forest-dwelling species and to examine the population genetic dynamics in coastal regions, in the context of Late Quaternary climatic and vegetational changes. The distribution area of E. fulgens includes regions where the forest shows signs of both expansion and retraction, allowing us to assess whether genetic patterns correspond to in situ Pleistocene survival or to glacial retreat and post-glacial expansion. Furthermore, if E. fulgens has been submitted to a different demographic scenario, we expect that genetic analyses would be consistent with historical population stasis and long-term persistence in regions where forest species showed signs of fragmentation and isolation, as indicated by previous studies in the same geographical range (Cabanne et al., 2007; PalmaSilva et al., 2009). Specifically, we use combined nuclear and plastid DNA data to address the following questions. (1) Was the current widespread distribution of E. fulgens stable during the Late Quaternary climatic oscillations? (2) Is there a northsouth genetic divergence, or are there disjunctions across the range of the species similar to those observed for species associated with forest habitats? (3) What is the current extent of genetic structure, and which past demographic processes may have shaped any phylogeographical patterns? (4) What is the relative contribution of seed versus pollen flow to historical gene flow? We discuss the phylogeographical and genetic structure of E. fulgens in the light of palaeoclimate, vegetation reconstructions and the biogeographical history of the BAF.

\section{MATERIALS AND METHODS}

\section{Plant material and sampling design}

Sixteen populations (Fig. 1a and Table 1) spanning the entire range of E. fulgens were sampled, covering c. $1000 \mathrm{~km}$. In total, 424 individuals across 16 populations were collected (Table 1). To avoid sampling the same individual twice, samples were collected at least $10 \mathrm{~m}$ apart. For molecular analysis, leaf samples were torn into small pieces and transferred into silica gel for drying. Total genomic DNA was extracted as described by Pinheiro et al. (2008a). (a)

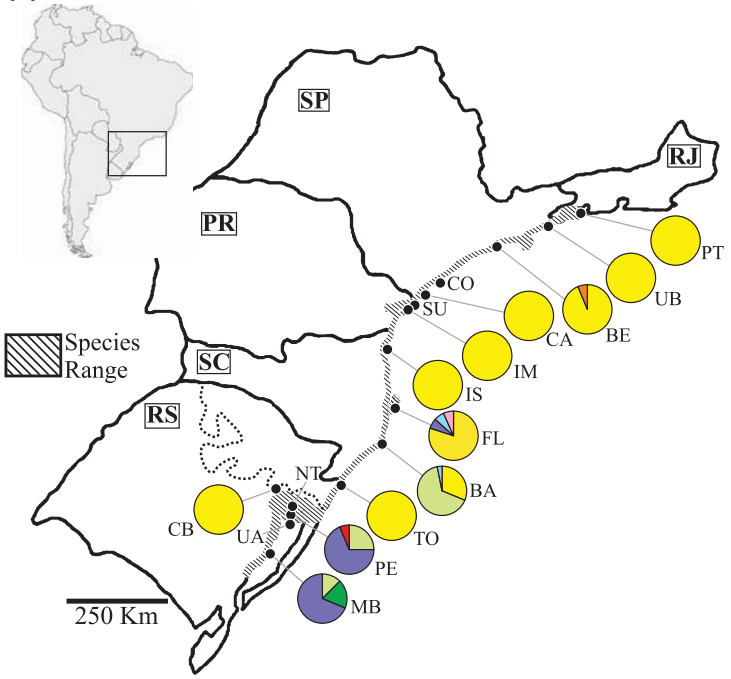

(b)

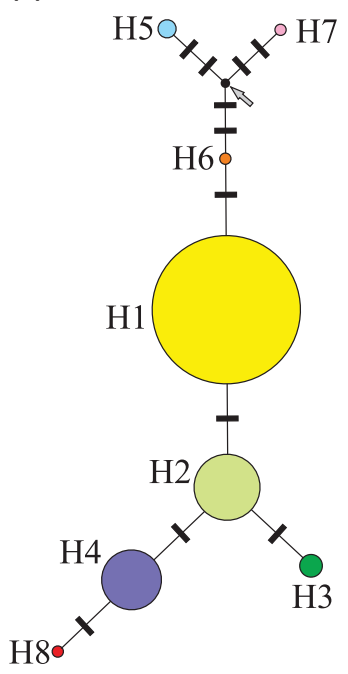

Figure 1 Map showing the current distribution of Epidendrum fulgens in southern and south-eastern Brazil, including populations sampled and genealogical relationships of the eight plastid DNA haplotypes recovered. (a) Pie charts reflect the frequency of occurrence of each haplotype in each population. Haplotype colours correspond to those shown in panel (b). The dotted line delimits the southern distribution of the Brazilian Atlantic Forest. (b) Statistical parsimony network linking the eight haplotypes. Haplotypes are designated by numbers, and circle sizes are proportional to haplotype frequencies. The number of mutations required to explain transitions among haplotypes is indicated along the lines connecting the haplotypes by the number of small bars. The arrow indicates a missing intermediate haplotype not found in the analysed individuals. Brazilian Federal States: RS, Rio Grande do Sul; SC, Santa Catarina; PR, Paraná; SP, São Paulo; RJ, Rio de Janeiro. 
Table 1 Populations sampled with their identification code, geographical coordinates, elevation ( $\mathrm{m}$ a.s.l.), habitat description and sample size analysed for nuclear and plastid markers of Epidendrum fulgens in southern and south-eastern Brazil. Populations are indicated as shown on the map in Fig. 1(a).

\begin{tabular}{|c|c|c|c|c|c|c|c|}
\hline \multirow[b]{2}{*}{ Population } & \multirow[b]{2}{*}{ ID } & \multirow[b]{2}{*}{ Latitude S } & \multirow[b]{2}{*}{ Longitude W } & \multirow[b]{2}{*}{ Elevation $(\mathrm{m})$} & \multirow[b]{2}{*}{ Habitat } & \multicolumn{2}{|c|}{ Sample size } \\
\hline & & & & & & Nuclear & Plastid \\
\hline Parati & PT & $23^{\circ} 10^{\prime}$ & $44^{\circ} 40^{\prime}$ & 5 & Sand-dune vegetation & 34 & 16 \\
\hline Ubatuba & UB & $23^{\circ} 22^{\prime}$ & $44^{\circ} 57^{\prime}$ & 16 & Sand-dune vegetation & 18 & 8 \\
\hline Bertioga & $\mathrm{BE}$ & $23^{\circ} 46^{\prime}$ & $45^{\circ} 57^{\prime}$ & 11 & Sand-dune vegetation & 20 & 16 \\
\hline Ilha Comprida & $\mathrm{CO}$ & $24^{\circ} 51^{\prime}$ & $47^{\circ} 42^{\prime}$ & 17 & Sand-dune vegetation & 20 & - \\
\hline Ilha do Cardoso & $\mathrm{CA}$ & $25^{\circ} 04^{\prime}$ & $47^{\circ} 54^{\prime}$ & 8 & Sand-dune vegetation & 29 & 16 \\
\hline Ilha de Superagui & SU & $25^{\circ} 27^{\prime}$ & $48^{\circ} 13^{\prime}$ & 9 & Sand-dune vegetation & 18 & - \\
\hline Ilha do Mel & IM & $25^{\circ} 31^{\prime}$ & $48^{\circ} 17^{\prime}$ & 7 & Sand-dune vegetation & 24 & 16 \\
\hline Ilha de São Francisco & IS & $26^{\circ} 16^{\prime}$ & $48^{\circ} 31^{\prime}$ & 16 & Sand-dune vegetation & 12 & 8 \\
\hline Florianópolis & $\mathrm{FL}$ & $27^{\circ} 37^{\prime}$ & $48^{\circ} 27^{\prime}$ & 7 & Sand-dune vegetation & 52 & 15 \\
\hline Imbituba & BA & $28^{\circ} 10^{\prime}$ & $48^{\circ} 41^{\prime}$ & 102 & Sand-dune vegetation & 50 & 32 \\
\hline Torres & TO & $29^{\circ} 22^{\prime}$ & $49^{\circ} 45^{\prime}$ & 7 & Sand-dune vegetation & 25 & 16 \\
\hline Morro Santana & NT & $30^{\circ} 03^{\prime}$ & $51^{\circ} 07^{\prime}$ & 293 & Granitic rock outcrop & 20 & - \\
\hline Morro São Pedro & $\mathrm{PE}$ & $30^{\circ} 11^{\prime}$ & $51^{\circ} 06^{\prime}$ & 185 & Granitic rock outcrop & 21 & 16 \\
\hline Morro do Cabrito & $\mathrm{CB}$ & $29^{\circ} 37^{\prime}$ & $51^{\circ} 39^{\prime}$ & 231 & Arenitic rock outcrop & 22 & 16 \\
\hline Itapuã & UA & $30^{\circ} 21^{\prime}$ & $51^{\circ} 02^{\prime}$ & 89 & Granitic rock outcrop & 37 & - \\
\hline Arambaré & $\mathrm{MB}$ & $30^{\circ} 54^{\prime}$ & $51^{\circ} 29^{\prime}$ & 8 & Sand-dune vegetation & 22 & 16 \\
\hline Overall & & & & & & 424 & 191 \\
\hline
\end{tabular}

\section{Molecular markers and genotyping assays}

Nine nuclear microsatellite markers were used in this study, six isolated from E. fulgens (markers EFF26, EFF29, EFF43, EFF45, EFF61, EFF70; Pinheiro et al., 2008a) and three isolated from E. puniceoluteum Pinheiro \& Barros (markers Epp10, Epp18, Epp86; Pinheiro et al., 2008b). Four plastid microsatellite loci (Epcp02, Epcp04, Epcp08, Epcp09; Pinheiro et al., 2009) were used for identifying and characterizing plastid DNA haplotypes. All polymerase chain reaction (PCR) amplifications were performed in an Applied Biosystems 2700 thermocycler (Applied Biosystems, Foster City, CA, USA) following the protocol described by Pinheiro et al. (2008a). The same conditions were used for all loci to maximize standardization. Microsatellite alleles were resolved on an ABI 3130 Genetic Analyzer automated sequencer and were sized with LIZ (500) standard using Genemapper 3.7 software (Applied Biosystems).

\section{Genetic diversity of sampled populations}

The nuclear microsatellite diversity of each population was characterized using the number of alleles $(A)$, number of private alleles $(P A)$, allelic richness $(A R)$, expected $\left(H_{\mathrm{E}}\right)$ and observed $\left(H_{\mathrm{O}}\right)$ heterozygosity, and the inbreeding coefficient $f$ (Weir \& Cockerham, 1984), calculated using the programs FSTAT 2.9.3.2 (Goudet, 1995) and MSA 4.05 (Dieringer \& Schlötterer, 2003). Departures from the Hardy-Weinberg equilibrium (HWE) for each population were identified using exact tests in GeNePop 4.0 (Raymond \& Rousset, 1995). The microsatellite data were tested for genotyping errors resulting from stuttering, short allele dominance and null alleles using a
Monte Carlo simulation of expected allele-size differences implemented in MICRO-CHECKER 2.2.3 (van Oosterhout et al., 2004).

Twelve populations were characterized for levels of diversity in plastid DNA markers. The number of haplotypes detected in each population, the haplotype diversity and the haplotype richness were estimated with the software RAREFAC 3.5 (Petit et al., 1998). Estimates of haplotype richness were corrected for differences in sample size using the rarefaction method.

\section{Biparental (nuclear) genetic structuring}

Genetic differentiation was measured across all populations using the fixation index $\theta$ (Weir \& Cockerham, 1984), the unbiased estimator of relative differentiation $G_{\mathrm{ST}}$ (Nei \& Chesser, 1983) and the standardized genetic differentiation measure $G_{\text {ST }}^{\prime}$ (Hedrick, 2005). Pairwise comparisons of $F_{\text {ST }}$ between populations were estimated using the program ARLEQUiN 3.5 (Excoffier \& Lischer, 2010). Partitioning of genetic diversity within and among populations was examined by analysis of molecular variance (AMOVA) implemented in the software ARLEQUIN 3.5.

The hypothesis that populations are differentiated because of isolation-by-distance was tested by assessing the correlation between pairwise geographical distances with pairwise values of $\theta, G_{\mathrm{ST}}$ and $G_{\mathrm{ST}}^{\prime}$ using a Mantel test in the program fSTAt. A total of 10,000 random permutations were performed. In addition, allelic richness and gene diversity were tested against latitude using Spearman's rank correlation coefficient to determine if there is a north-south pattern of genetic diversity. The relationships between latitude and genetic parameters 
were tested by linear, quadratic and cubic regression models, and the most likely model was selected based on the highest percentage variance explained $\left(\mathrm{PVE}=R^{2}\right)$.

Bayesian assignment analysis (in STRUCTURE 2.3.3; Hubisz et al., 2009) was used to assign individuals to genetic clusters $(K)$ and estimate admixture proportions (Q) for each individual. Following the new model developed for sTRUCTURE, information of sampling localities was considered in the assignment tests. A set of models was chosen in which individuals had admixed ancestries and correlated allele frequencies. The number of $K$ was set from a minimum of one to a maximum of ten, and two simulations were run for each $K$-value with a burn-in of 100,000 and 300,000 iterations, respectively. To define the most probable number of genetic clusters $(K)$ present in the data, we used the method proposed by Evanno et al. (2005), which is based on an ad hoc measure $\Delta K$ that evaluates the second-order rate of change of the likelihood function with respect to $K$. Replicated runs were performed for each of the 10 models $(K=1-10)$ a minimum of three times to ensure consistent natural log probabilities.

\section{Maternal (plastid) genetic structuring}

A median-joining (MJ) network (Bandelt et al., 1999) was constructed based on plastid DNA to visualize the relationships among haplotypes, using the program NETWORK 4.5.1.0 (http://www.fluxus-engineering.com). It uses maximum parsimony to reconstruct all possible shortest, least complex phylogenetic trees. Pairwise comparisons of $F_{\mathrm{ST}}$ between populations were calculated, and AMOVA was conducted using the software ARLEQUIN. Genetic differentiation was also measured by $F_{\mathrm{ST}}$ and $G_{\mathrm{ST}}$, using the program PERMUT/CPSSR 2.0 (Pons \& Petit, 1996). To search for a north-south gradient of genetic diversity, haplotype richness and haplotype diversity were tested against latitude, using the same procedure as for the nuclear markers.

\section{Bottleneck tests}

Recent population size reductions (i.e. genetic bottlenecks) were tested based on heterozygosity excess using the coalescent approach implemented in the program вотTLENECK 1.2.02 (Cornuet \& Luikart, 1996). The analysis was carried out under the two-phase model (TPM), which is known to fit microsatellite evolution better than other methods (Dirienzo et al., 1994), with 95\% contribution from the stepwise mutation model (or strict single-step mutations) and 5\% contribution from the multiple-step mutations, for which the variance for mutation size was set to 12 as suggested in the user's manual. Statistical significance was assessed by 10,000 replications using a one-tailed Wilcoxon signed-rank test of mutation $(M)$. The $M$-statistic values were calculated for each population according to Garza \& Williamson (2001) to detect reductions in effective population size, using the software ARLEQUIN. Significance was assessed by comparison between the mean value $M$ across all loci and the value $M=0.680$, the threshold value below which a population can reasonably be assumed to have undergone a reduction in population size (Garza \& Williamson, 2001).

\section{Gene flow by pollen and seed dispersal}

The combined analysis of nuclear and plastid genomes allowed inferences to be made regarding the relative levels of gene flow by pollen and by seed, by comparing $G_{\mathrm{ST}}$ values from biparentally inherited nuclear markers $\left(G_{\mathrm{STb}}\right)$ with those from uniparentally inherited plastid markers $\left(G_{\mathrm{STm}}\right)$ (Ennos, 1994; Petit et al., 2005). The relative contribution of pollen versus seed flow to total gene flow was estimated following Ennos (1994) and Petit et al. (2005), using equation 1 presented by Petit et al. (2005):

Pollen flow/seed flow

$$
=\left[\left(1 / G_{\mathrm{STb}}-1\right)\left(1+F_{\mathrm{IS}}\right)-2\left(1 / G_{\mathrm{STm}}-1\right)\right] /\left(1 / G_{\mathrm{STm}}-1\right) \text {. }
$$

\section{RESULTS}

\section{Genetic variation at sampled populations}

For the 16 sites genotyped with nuclear markers, high levels of genetic diversity were observed for all genetic parameters (Table 2). The number of alleles ranged from 49 to 117 , and the allelic richness ranged from 4.49 to 6.94 . The expected and observed heterozygosity per population ranged from 0.597 to 0.761 and from 0.454 to 0.720 , respectively. One to four private alleles were observed in almost all populations. The inbreeding coefficients were low in most populations, ranging from -0.004 to 0.245 . Only five populations (Bertioga, Ilha Comprida, Imbituba, Morro São Pedro and Itapuã) displayed significant departures from HWE owing to heterozygote deficits. Genotyping errors, such as null alleles, were ruled out by MiCRO-CHECKER tests.

For the four plastid microsatellite loci, we detected 8 haplotypes from 12 sampling locations (Fig. 1a; Table 2). Haplotype richness ranged from 0.000 to 1.667 , and haplotype diversity ranged from 0.000 to 0.508 . Seven out of 12 populations sampled for plastid markers had a fixed haplotype (H1).

\section{Genetic structure and population differentiation revealed by nuclear markers}

Low levels of differentiation across populations were found for $\theta(0.067), G_{\mathrm{ST}}(0.097)$ and $G_{\mathrm{ST}}^{\prime}(0.297)$. The $F_{\mathrm{ST}}$ values calculated for each pair of populations ranged from -0.033 to 0.377 , and most values observed were significant $(P<0.05$; Table 3). Generally, the lowest $F_{\mathrm{ST}}$ values were observed between adjacent populations (Table 3).

Geographical distances were significantly correlated with nuclear genetic differentiation as estimated by $\theta\left(R^{2}=0.359\right.$, $P<0.0001), G_{\mathrm{ST}}\left(R^{2}=0.496, \mathrm{P}<0.0001\right)$ and $G_{\mathrm{ST}}^{\prime}\left(R^{2}=\right.$ $0.533, P<0.0001)$, suggesting the presence of isolation-by- 
Table 2 Characterization of genetic variability in Epidendrum fulgens populations in southern and south-eastern Brazil. The number of alleles $(A)$, number of private alleles $(P A)$, allelic richness $(A R)$, expected $\left(H_{\mathrm{E}}\right)$ and observed $\left(H_{\mathrm{O}}\right)$ heterozygosity and the within-population inbreeding coefficient $f$ were estimated from nine nuclear microsatellite loci for 424 individuals. The number of haplotypes $(N H)$, haplotype richness $(H R)$ and haplotype diversity $(H D)$ were estimated from four plastid microsatellite loci for 191 specimens. See Table 1 for sample size details for each population.

\begin{tabular}{|c|c|c|c|c|c|c|c|c|c|}
\hline \multirow[b]{2}{*}{ Population/Code } & \multicolumn{6}{|c|}{ Nuclear microsatellites } & \multicolumn{3}{|c|}{ Plastid microsatellites } \\
\hline & $A$ & $P A$ & $A R$ & $H_{\mathrm{E}}$ & $H_{\mathrm{O}}$ & $f$ & NH & $H R$ & $H D$ \\
\hline Parati/PT & 64 & 4 & 4.63 & 0.622 & 0.573 & 0.080 & 1 & 0.000 & 0.000 \\
\hline Ubatuba/UB & 49 & 0 & 4.49 & 0.599 & 0.574 & 0.042 & 1 & 0.000 & 0.000 \\
\hline Bertioga/BE & 63 & 2 & 5.17 & 0.597 & 0.454 & $0.245^{\star * *}$ & 2 & 0.500 & 0.125 \\
\hline Ilha Comprida/CO & 77 & 0 & 5.26 & 0.686 & 0.616 & $0.105^{\star}$ & - & - & - \\
\hline Ilha do Cardoso/CA & 76 & 1 & 5.48 & 0.601 & 0.580 & 0.036 & 1 & 0.000 & 0.000 \\
\hline Ilha de Superagui/SU & 77 & 1 & 6.36 & 0.652 & 0.593 & 0.094 & - & - & - \\
\hline Ilha do $\mathrm{Mel} / \mathrm{IM}$ & 74 & 0 & 5.78 & 0.644 & 0.573 & 0.113 & 1 & 0.000 & 0.000 \\
\hline Ilha de São Francisco/IS & 69 & 2 & 6.39 & 0.688 & 0.650 & 0.057 & 1 & 0.000 & 0.000 \\
\hline Florianópolis/FL & 117 & 2 & 6.94 & 0.722 & 0.686 & 0.050 & 4 & 1.600 & 0.371 \\
\hline Imbituba/BA & 106 & 3 & 6.89 & 0.761 & 0.689 & $0.096^{* * *}$ & 3 & 1.220 & 0.486 \\
\hline Torres/TO & 98 & 3 & 6.81 & 0.723 & 0.702 & 0.029 & 1 & 0.000 & 0.000 \\
\hline Morro Santana/NT & 62 & 1 & 5.42 & 0.694 & 0.630 & 0.095 & - & - & - \\
\hline Morro São Pedro/PE & 76 & 2 & 6.10 & 0.736 & 0.632 & $0.144^{* *}$ & 3 & 1.462 & 0.492 \\
\hline Morro do Cabrito/CB & 69 & 2 & 5.49 & 0.697 & 0.638 & 0.087 & 1 & 0.000 & 0.000 \\
\hline Itapuã/UA & 88 & 2 & 6.09 & 0.702 & 0.627 & $0.109^{* * *}$ & - & - & - \\
\hline Arambaré/MB & 66 & 1 & 5.51 & 0.717 & 0.720 & -0.004 & 3 & 1.667 & 0.508 \\
\hline
\end{tabular}

Departures from Hardy-Weinberg equilibrium, with Bonferroni correction, are indicated by asterisks $\left({ }^{*} P<0.05,{ }^{* *} P<0.005,{ }^{* *} P<0.0005\right)$.

Table $3 F_{\text {ST }}$ values for pairwise comparison between populations of Epidendrum fulgens in southern and south-eastern Brazil based on nuclear (below diagonal) and plastid (above diagonal) microsatellites. Dashes indicate populations that were not analysed with plastid markers. See Table 1 for population identification.

\begin{tabular}{|c|c|c|c|c|c|c|c|c|c|c|c|c|c|c|c|c|}
\hline & PT & UB & $\mathrm{BE}$ & $\mathrm{CO}$ & CA & SU & IM & IS & FL & BA & TO & NT & PE & $\mathrm{CB}$ & UA & MB \\
\hline PT & * & 0.000 & 0.000 & - & 0.000 & - & 0.000 & 0.000 & 0.069 & 0.484 & 0.000 & - & 0.859 & 0.000 & - & 0.791 \\
\hline UB & 0.135 & * & -0.050 & - & 0.000 & - & 0.000 & 0.000 & 0.004 & 0.423 & 0.000 & - & 0.816 & 0.000 & - & 0.731 \\
\hline $\mathrm{BE}$ & 0.036 & 0.029 & * & - & 0.000 & - & 0.000 & -0.050 & 0.037 & 0.461 & 0.000 & - & 0.825 & 0.000 & - & 0.760 \\
\hline $\mathrm{CO}$ & 0.041 & 0.034 & 0.016 & * & - & - & - & - & - & - & - & - & - & - & - & - \\
\hline $\mathrm{CA}$ & -0.002 & 0.084 & 0.046 & 0.015 & * & - & 0.000 & 0.000 & 0.069 & 0.484 & 0.000 & - & 0.859 & 0.000 & - & 0.791 \\
\hline SU & 0.056 & 0.032 & 0.025 & 0.002 & 0.012 & * & - & - & - & - & - & - & - & - & - & - \\
\hline IM & 0.005 & 0.062 & 0.118 & 0.031 & 0.008 & -0.009 & * & 0.000 & 0.069 & 0.484 & 0.000 & - & 0.859 & 0.000 & - & 0.791 \\
\hline IS & 0.035 & 0.121 & 0.149 & 0.115 & 0.038 & 0.032 & 0.032 & * & 0.004 & 0.423 & 0.000 & - & 0.816 & 0.000 & - & 0.731 \\
\hline $\mathrm{FL}$ & 0.060 & 0.106 & 0.106 & 0.071 & 0.029 & 0.033 & 0.035 & 0.010 & $*$ & 0.281 & 0.069 & - & 0.580 & 0.069 & - & 0.529 \\
\hline BA & 0.047 & 0.134 & 0.111 & 0.087 & 0.023 & 0.057 & 0.057 & 0.020 & -0.004 & * & 0.484 & - & 0.485 & 0.484 & - & 0.440 \\
\hline TO & 0.123 & 0.115 & 0.167 & 0.135 & 0.093 & 0.058 & 0.076 & 0.011 & 0.021 & 0.044 & * & - & 0.859 & 0.000 & - & 0.791 \\
\hline NT & 0.169 & 0.170 & 0.228 & 0.175 & 0.147 & 0.071 & 0.133 & 0.071 & 0.055 & 0.099 & 0.039 & * & - & - & - & - \\
\hline $\mathrm{PE}$ & 0.128 & 0.126 & 0.157 & 0.111 & 0.112 & 0.033 & 0.092 & 0.057 & 0.062 & 0.099 & 0.052 & -0.004 & * & 0.859 & - & -0.001 \\
\hline СВ & 0.140 & 0.128 & 0.189 & 0.132 & 0.114 & 0.030 & 0.091 & 0.054 & 0.037 & 0.076 & 0.038 & -0.012 & 0.012 & * & - & 0.791 \\
\hline UA & 0.175 & 0.157 & 0.216 & 0.181 & 0.139 & 0.099 & 0.143 & 0.027 & 0.001 & 0.045 & -0.033 & -0.002 & 0.024 & -0.021 & * & - \\
\hline MB & 0.282 & 0.311 & 0.377 & 0.331 & 0.273 & 0.223 & 0.257 & 0.140 & 0.118 & 0.171 & 0.069 & 0.053 & 0.105 & 0.062 & 0.040 & * \\
\hline
\end{tabular}

Values given in bold are significant at $P<0.05$.

distance. The distribution of genetic diversity across the range of the sampled populations was negatively correlated with latitude (allelic richness, $P<0.05 ; H_{\mathrm{E}}, P<0.0001$ ). The relationship between genetic diversity and latitude was best described by the quadratic model (allelic richness, $R^{2}=0.755$; $\left.H_{\mathrm{E}}, R^{2}=0.738\right)$. The model indicated higher values for the mid-southern populations Florianópolis, Imbituba and Torres, with a tendency to decrease in both directions towards the range margins (Fig. 2a,b).

Simulations performed in STRUCTURE consistently identified $K=2$ clusters, as show in Appendix S3. The admixture proportions $Q$ for each individual are shown in Fig. 3. 

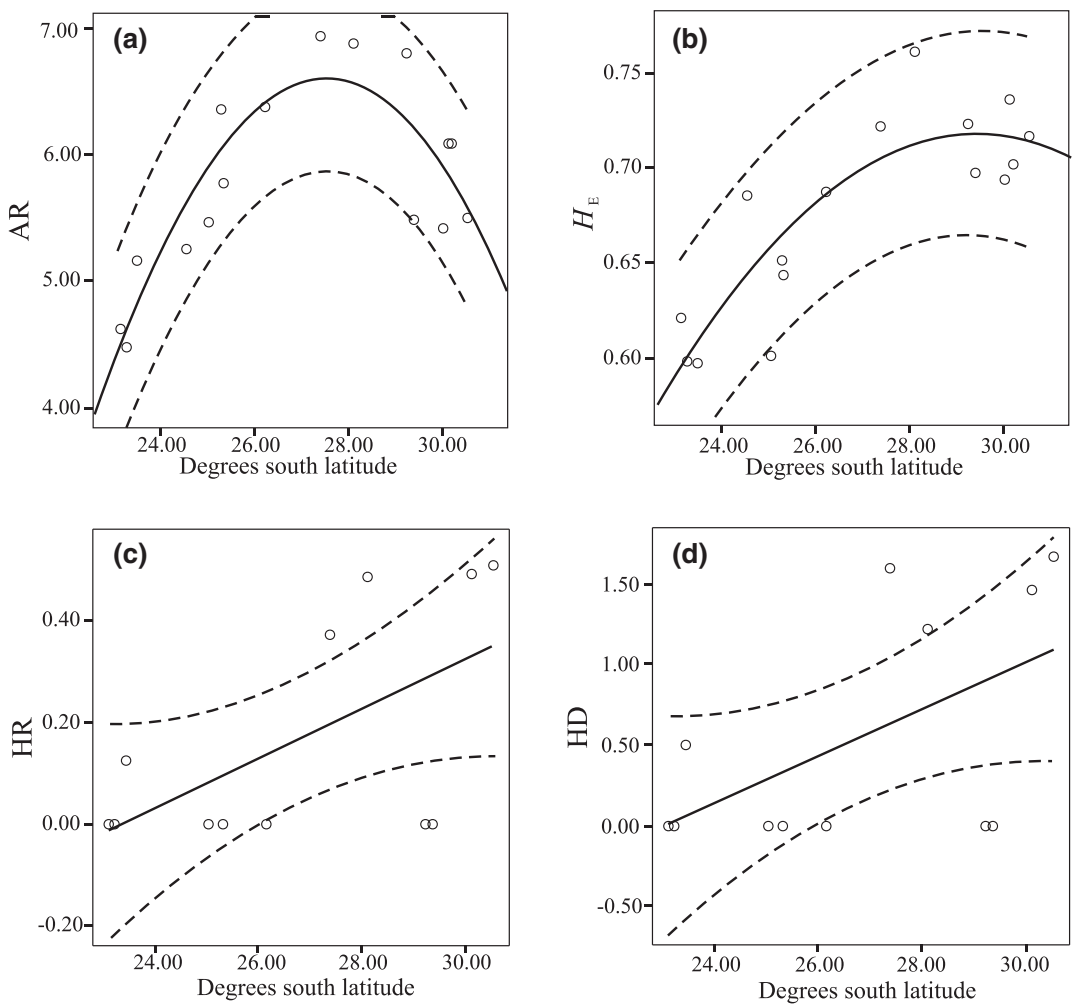

Figure 2 Geographical trends of genetic parameters of Epidendrum fulgens populations in southern and south-eastern Brazil. Correlation between latitude and (a) nuclear allelic richness $\left(A R, R^{2}=0.755, P<0.05\right)$ and (b) nuclear genetic diversity $\left(H_{\mathrm{E}}, R^{2}=0.738, P<0.0001\right)$ described by the quadratic regression model, and (c) plastid haplotype richness $\left(H R, R^{2}=0.331, P<0.05\right)$ and (d) plastid haplotype diversity $\left(H D, R^{2}=0.239, P<0.05\right)$ described by the linear regression model, showing a significant decrease in diversity estimates towards the north. Dashed lines represent 95\% confidence intervals calculated based on individual predicted $y$ values from the regression line (as indicated in SPSS v.13.0).

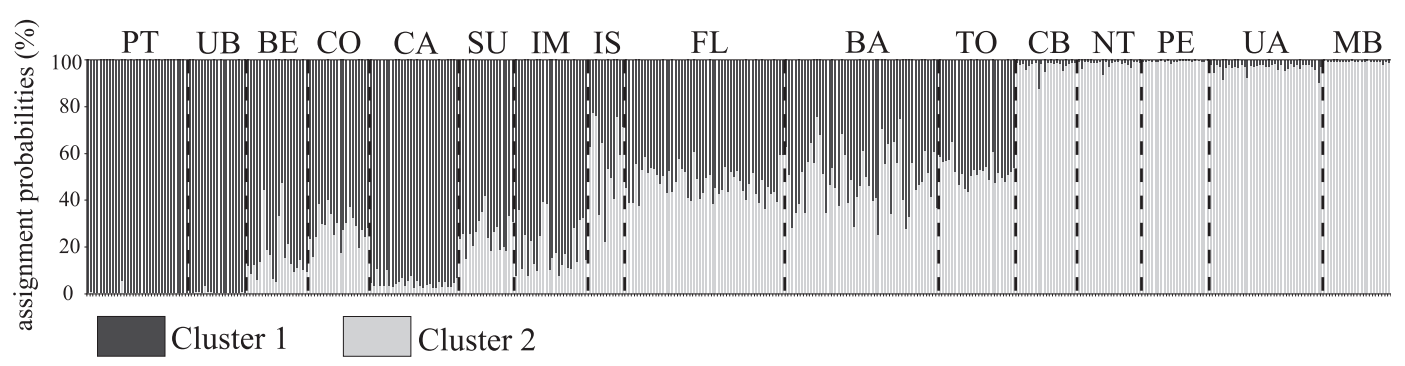

Figure 3 Summary of the population structure in Epidendrum fulgens in southern and south-eastern Brazil using Bayesian assignment analysis for a $K=2$ population model. Cluster 1 corresponds to northern populations and cluster 2 to southern populations. See Table 1 for population identification.

Almost all individuals from the northernmost populations PT and UB show a strong assignment to cluster $1(Q<0.95)$, whereas the southernmost populations MB, UA, PE, NT and $\mathrm{CB}$ show admixture proportions strongly associated with cluster $2(Q>0.95)$. The remaining populations show intermediate admixture proportions between northern (PT and $\mathrm{UB})$ and southern (MB, UA, PE, NT and $\mathrm{CB})$ populations. AMOVA results indicate that the majority of the genetic variation resides within populations (91.64\%, $P<0.0001$ ), and only $8.36 \%$ of the nuclear diversity is found among populations.

\section{Plastid DNA genetic structure}

Statistical parsimony retrieved a well-resolved network (Fig. 1b), in which the most frequent and widespread haplotype (H1) was found in $69.6 \%$ of the individuals and in 10 out of 12 sampled populations. $\mathrm{H} 1$ is distributed from the northernmost population $\mathrm{PT}$ to population $\mathrm{CB}$, which is situated on the southern border of the BAF (Fig. 1a). This was also the fixed haplotype in seven populations (PT, UB, CA, IM, IS, TO and $\mathrm{CB}$ ). Haplotype $\mathrm{H} 2$ is restricted to the southern populations $\mathrm{MB}, \mathrm{PE}$ and $\mathrm{BA}$ and forms the core of the network 
topology, to which three other haplotypes are connected (H3, H4, H8). Haplotypes $\mathrm{H} 5$ and $\mathrm{H} 7$ are more differentiated and connected to the network by more than one mutational step. These divergent haplotypes are found in the Florianópolis and Imbituba populations, which also show higher levels of variation for nuclear and plastid markers. According to the AMOVA results, a high proportion of the genetic variability in the haplotype data resides among populations (60.57\%, $P<0.0001)$, and only $39.43 \%(P<0.0001)$ was attributed to within populations. Pairwise $F_{\mathrm{ST}}$ values among populations ranged from -0.050 to 0.859 (Table 3 ). In general, lower $F_{\mathrm{ST}}$ values were observed between adjacent populations (Table 3 ). Differentiation measures across all populations were high, with $F_{\mathrm{ST}}=0.605$ and $G_{\mathrm{ST}}=0.618$. A significant decrease in haplotype richness $(P<0.05)$ and haplotype diversity $(P<0.05)$ was found towards the north (Fig. 2c,d, respectively), similar to the pattern found for nuclear markers. For plastid markers, the relationship between genetic diversity and latitude was best described by a linear model (haplotype richness, $R^{2}=0.331$; haplotype diversity, $R^{2}=0.239$ ).

\section{Historical population size reduction}

Wilcoxon signed-rank tests did not reveal any significant excesses of heterozygosity under the TPM, indicating that

Table 4 Bottleneck test probabilities of 16 natural Epidendrum fulgens populations in southern and south-eastern Brazil based on estimates of nuclear multilocus genotypes. Wilcoxon signed-rank tests under the two-phase model of mutation (TPM) were used to test for heterozygote excess, and the mean Garza-Williamson index $(M)$ was used to compare allele numbers with allele size ranges.

\begin{tabular}{lll}
\hline Population & TPM $^{*}$ & $M \dagger$ \\
\hline Parati & 0.981 & 0.646 \\
Ubatuba & 0.751 & 0.653 \\
Bertioga & 0.935 & 0.804 \\
Ilha Comprida & 0.849 & 0.815 \\
Ilha do Cardoso & 0.849 & 0.771 \\
Ilha de Superagui & 0.820 & 0.726 \\
Ilha do Mel & 0.751 & 0.770 \\
Ilha de São Francisco & 0.673 & 0.741 \\
Florianópolis & 0.820 & 0.834 \\
Imbituba & 0.500 & 0.878 \\
Torres & 0.714 & 0.743 \\
Morro Santana & 0.500 & 0.754 \\
Morro São Pedro & 0.367 & 0.777 \\
Morro do Cabrito & 0.975 & 0.777 \\
Itapuã & 0.986 & 0.794 \\
Arambaré & 0.632 & 0.740 \\
\hline
\end{tabular}

${ }^{\star}$ No values were significant $(P>0.05)$.

$\dagger$ A population is considered to have undergone a bottleneck if its $M$-value falls below a threshold of 0.680 , following the procedure described by Garza \& Williamson (2001).

†Populations in which bottlenecks were detected according to Garza \& Williamson (2001). populations have not experienced a recent or a strong bottleneck. By contrast, $M$-ratios suggested that bottlenecks have occurred in the northern portion of the distribution of E. fulgens, in populations PT (0.646) and UB (0.653). Across all sites and loci, the $M$-ratio ranged from 0.646 to 0.878 (Table 4).

\section{Pollen versus seed flow}

Using the values of genetic differentiation $G_{\mathrm{ST}}$ among populations for nuclear (0.097) and plastid (0.618) markers, the ratio of pollen flow to seed flow was estimated at 14.25, suggesting that gene flow via pollen in E. fulgens is more than tenfold greater than that via seeds.

\section{DISCUSSION}

\section{Deep disjunction between southern and northern populations}

The most outstanding pattern recovered by the joint use of plastid and nuclear markers was the deep differentiation of populations of E. fulgens located south of Torres (seashore) and Morro do Cabrito (remnant calcareous outcrops from the lower slopes of the 'Serra Geral'). This region represents the southern limits of the BAF (Fig. 1a), coincident with the end of the Serra Geral mountain chain. Located approximately between $29^{\circ}$ and $30^{\circ} \mathrm{S}$, this region of disjunction is recognized historically as an important phytogeographical boundary, called the 'Portal de Torres' (Rambo, 1950). The 'Portal de Torres' demarcates the northern limits of subtropical grassland plant communities and the southern limits of the BAF, and the deep genetic differentiation between populations within the BAF and those located on southern granitic outcrops probably reflects a historical vicariance pattern. Because the LGM had different impacts on forest and grassland plant communities, the results presented here highlight the importance of studies including species distributed across different biomes.

\section{Genetic structure and diversity within the BAF}

There is a lack of phylogeographical structure across the populations analysed within the BAF, considering both nuclear and plastid markers (Figs 1a \& 3 ). In addition, nuclear markers show low genetic differentiation with regard to $\theta, G_{\mathrm{ST}}$ and

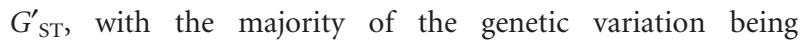
partitioned within populations. Indeed, there are no clear recognizable geographical barriers along the seashore where E. fulgens occurs, at least for populations from Parati to Torres. A different pattern has been reported for other species associated with humid forest (Cabanne et al., 2007; PalmaSilva et al., 2009; Ribeiro et al., 2011), which show strong phylogeographical structure and evidence of past forest fragmentation, congruent with the contraction of the BAF during the LGM. With a decrease in temperature of $3-7^{\circ} \mathrm{C}$ during the LGM, open scrub and grasslands were the dominant vegetation 
in southern and south-eastern Brazilian lowlands close to the seashore, where tropical rain forest currently exists (Behling \& Negrelle, 2001; Behling, 2002). As open scrub and grasslandtype vegetation communities are the current habitats occupied by E. fulgens, the absence of phylogeographical structure in our results is in agreement with palaeovegetation reconstructions, suggesting a non-fragmented distribution during the LGM for this species. Our data are also in agreement with a scenario found for other non-forest species (Jakob et al., 2009; Antonelli et al., 2010; Cosacov et al., 2010) and sand-dune plants (Kadereit et al., 2005; King et al., 2009), suggesting that during the LGM a significant proportion of species did not undergo dramatic range fragmentation into separate glacial refugia.

A marked decrease in genetic diversity was found in both nuclear and plastid markers towards the north (Fig. 2). The two northern populations PT and UB also showed signs of severe population decline (i.e. bottlenecks). The lower levels of genetic diversity coupled with the significant population size reduction detected in the northern distribution of $E$. fulgens suggest that the expansion of the BAF towards the south, after the LGM, played a role in limiting the availability of habitat for this species, reducing local densities. Formerly widespread species subjected to transitory reductions in population sizes, caused generally by bottlenecks or founder events, show a reduction of genetic diversity, a pattern observed in most phylogeographical analyses within the BAF biome (Cabanne et al., 2007; Palma-Silva et al., 2009; Ribeiro et al., 2011). As a result of forest expansion and sea-level rise after the LGM, restinga vegetation was constrained to a narrow $(20-50 \mathrm{~m}$ wide) and patchy distribution mainly between latitudes $23^{\circ}$ and $24^{\circ} \mathrm{S}$ (Souza et al., 2008), including the locations of populations $\mathrm{PT}, \mathrm{UB}$ and BE. This pattern gradually changed towards the south, where sand dunes in restinga became wider (1-10 km) and more connected (Seeliger, 1992). When population isolation increases and population density decreases, genetic drift becomes stronger and reduces genetic diversity, mainly in peripheral populations (Eckert et al., 2008). The occurrence of private alleles in populations in the northern part of the distribution of E. fulgens also indicates that individuals in those populations represent long-term persistence rather than recent migration from southern populations, as reported in the literature for a wide range of organisms (e.g. Burton, 1997; Stehlik et al., 2002; Antunes et al., 2006; Ortiz et al., 2007; Jakob et al., 2009).

\section{Disjunct populations on granitic outcrops}

A different picture is observed for southern populations of E. fulgens, where both diversity and structure were higher than in northern localities (Figs 1a \& 2). Assignment probabilities show a tendency of differentiation for populations south of Torres, based on nuclear markers (Fig. 3). Plastid markers also show a marked differentiation in haplotype frequencies in the same region. The fixed haplotype (H1) found in Torres and Morro do Cabrito can be explained by an east-west migration bridge of typical species from the BAF, from the seashore to the west over the lowlands of the Central Depression and the lower north-eastern slopes of the Serra Geral (Rambo, 1950; Leal \& Lorscheitter, 2007). The Morro do Cabrito population shows nuclear admixture proportions characteristic of southern populations (Fig. 3) and haplotypes typical of northern populations (H1, Fig. 1a). This conflicting pattern found in Morro do Cabrito is probably due to its intermediate position, marking the border between the BAF and southern grassland biomes (Fig. 1a).

Populations of E. fulgens from southern granitic outcrops (populations NT, PE, UA) showed a considerable proportion of genetic diversity and a marked difference in allele frequencies for both nuclear and plastid markers. The remarkable genetic diversity of these populations suggests that these localities acted as refugial areas during oceanic transgressions. Successive marine transgressions occurring from the Late Pleistocene created a mosaic of swamps, lakes and small patches of forest in the lowlands, isolating the granitic outcrops from the seashore sand-dune vegetation (Seeliger, 1992) and constraining gene exchange with sand-dune populations located within the BAF. Floristic inventories of these outcrops reveal a considerable proportion of endemic and rare species (Ferreira et al., 2010), indicating that these granitic hills were refugial areas during marine transgression events for both forest and grassland species (Rambo, 1954a). Both the higher elevation and the presence of patches of exposed rocks and shallow soil allowed the presence of grassland and open scrub plant communities even during warmer and more humid periods, creating the mosaic of forest/grassland species currently observed (Rambo, 1954a; Ferreira et al., 2010). The Arambaré population was probably colonized from populations sheltered in the granitic hills, after Holocene sea transgressions, when sand dunes at this locality were formed (Seeliger, 1992).

\section{Population genetic signatures and historical sea-level oscillation}

The historical oscillation of sea level could also have played a role in limiting the plastid genetic diversity of populations from Parati to Torres. According to Seeliger (1992) and Behling (2002), successive marine transgressions and regressions occurred during the Pleistocene and Holocene, negatively affecting coastal vegetation as observed in the low number of endemic species in this habitat (Rambo, 1954b; Scarano, 2002). Generally, the restinga vegetation is composed of a subsample of species from the BAF and grasslands that are adapted to harsh environments and exhibit broad ecological amplitude (Scarano, 2002). Populations at Imbituba and Florianópolis are exceptions to this pattern, because high genetic diversity was observed for both nuclear and plastid markers. Those populations are directly associated with (Imbituba) or close to (Florianópolis) sheltered areas related to Pleistocene barriers (Hesp et al., 2009). These barriers were sand deposits initiated 
during the Last Interglacial, at c. $120 \mathrm{ka}$ (Hesp et al., 2009). The vegetation found on these barriers was protected during the sea-level oscillations of the late Holocene owing to their height above sea level $(50-100 \mathrm{~m})$. This offered a stable environment where sand-dune vegetation could persist, constituting a probable refugium for those species (Rambo, 1954b; Seeliger, 1992; Hesp et al., 2009).

\section{The role of gene flow in shaping broad-scale genetic patterns}

Gene flow among E. fulgens populations proved to be tenfold greater via pollen than via seeds. This result is not expected for orchid species, which are characterized by dust-like seeds dispersed by wind (Arditti \& Ghani, 2000). Moreover, nuclear markers did not show strong evidence of genetic structuring among E. fulgens populations, also suggesting high levels of gene flow by pollen. Gene flow between granitic outcrops and sand-dune populations within the BAF is probably constrained only by reduced seed dispersal, as the plastid genetic differentiation observed between adjacent populations is great (Table 3).

For two other food-deceptive orchids, Galearis cyclochila (as Orchis cyclochila, Chung et al., 2005) and Orchis purpurea (Jacquemyn et al., 2006), empirical data obtained for contemporary gene flow estimations suggest that seeds have only a limited dispersal capacity. In deceptive orchids outcrossing prevails because pollinators avoid plants in the same patch, promoting pollen gene flow over long distances and reducing the chances of geitonogamous pollination (Cozzolino \& Widmer, 2005). Extensive pollen transport between E. fulgens populations is supported by the low inbreeding coefficients, high proportion of genetic diversity within populations and low population differentiation. The genetic signatures observed in populations of E. fulgens are in agreement with and confirm the genetic structure expected for food-deceptive orchids (Cozzolino \& Widmer, 2005). The significant isolation-by-distance detected and the low differentiation between adjacent populations (Table 3) suggest that pollen dispersal performed by butterflies may be restricted to neighbouring populations. However, the lack of nuclear genetic structure among populations may suggest pollen transport by butterflies over longer distances. As reviewed by van der Cingel (2007), species of Lepidoptera can contribute substantially to pollen transport of orchid species over long distances. Results found for other food-deceptive orchids showed different patterns, however. For Anacamptis palustris (Cozzolino et al., 2003) and Dactylorhiza majalis (Nordström \& Hedrén, 2009), seedmediated gene flow was greater than gene flow via pollen (pollen:seed flow ratios of 0.48 and 0.30 , respectively). According to the authors, these results need to be interpreted with caution as populations of those species are restricted to specialized habitats and show a disjunct, patchy distribution, which constrains gene flow among populations (Cozzolino et al., 2003; Nordström \& Hedrén, 2009). Fine-scale spatial genetic structure coupled with progeny analyses (Chung et al.,
2005; Jacquemyn et al., 2006) may clarify the role of pollenmediated gene flow in Epidendrum populations.

Populations on range margins displayed lower genetic diversity than did central populations, mainly for nuclear allelic richness (Fig. 2a). Increased drift resulting from reduced gene flow on marginal populations (Table 3), combined with reduced density (Allee effect) and reduced mutational input in marginal populations, may contribute to the reduced levels of diversity observed at range margins (Bridle \& Vines, 2007; Eckert et al., 2008). Theoretical models of evolution in range margins commonly consider factors such as density, drift, gene flow and selection along a selective gradient (Kirkpatrick \& Barton, 1997; Bridle \& Vines, 2007), that is, at a spatial scale that is finer than the one studied here; future studies on the limits of evolution in the range margins of E. fulgens should explicitly focus on this scale at both the northern and southern margins.

\section{CONCLUSIONS}

The present phylogeographical study of $E$. fulgens reveals the influence of contrasting and complex geological and climatic events on patterns of diversification and distribution in this orchid species. The deep disjunction detected between northern populations within the BAF region and southern populations outside the BAF is probably associated with successive marine transgressions occurring from the Late Pleistocene. This historical vicariance pattern is geographically coincident with the northern limits of subtropical grassland plant communities and the southern limits of the BAF, traditionally called 'Portal de Torres'. The scenario depicted by our analytical approach suggests that E. fulgens was widespread during the LGM, rather than being isolated in only a few refugia. The expansion of grassland habitats, as revealed by palynological data for the LGM, apparently had a positive effect on the population persistence of species associated with sand-dune and rock outcrop plant communities. Populations found on Pleistocene sand barriers and granitic outcrops in the southern part of the range of E. fulgens showed increased levels of genetic diversity, probably due to the age and stability of those locations. Bottlenecks were detected in the two northern populations, suggesting that forest expansion towards the south after the LGM, followed by narrowing of the coastal sands and sea-level rise, played a role in the population fragmentation and decrease in genetic diversity in this species. Private alleles found across most of the populations indicate the long-term persistence of these populations, rather than recent migrations. The phylogeographical pattern for this coastal orchid species differs substantially from that of forest-associated species within the BAF, which underwent substantial bottlenecks in glacial refugia during the Pleistocene (Cabanne et al., 2007; Palma-Silva et al., 2009; Ribeiro et al., 2011). The results highlight the substantial contribution of species growing outside the forests to our knowledge of past vegetation and climate dynamics in the Neotropics. 


\section{ACKNOWLEDGEMENTS}

We thank V. Tranchida-Lombardo and R. Rinaldi for help in the laboratory, and D. Fuhro, C.M. Zanella, R.B. Louzada, R.B. Singer, C. Kameyama, J.L. Waechter, R.B. Setubal and S. Koehler for help during fieldwork. Funding for this study was provided by grants from the Prance Fellowship in Neotropical Botany under the Kew Latin American Research Fellowship Programme (KLARF) to F.P. and from Conselho Nacional de Desenvolvimento Científico e Tecnológico (CNPq-471929/2006-9) and Fundação de Amparo à Pesquisa do Estado de São Paulo to F.B. (FAPESP - 06/54189-3) and C.P. (FAPESP - 2009/527253; 2009/174118). F.P received a fellowship from $\mathrm{CNPq}$ and CAPES, and F.B. received a productivity grant from $\mathrm{CNPq}$.

\section{REFERENCES}

Antonelli, A., Verola, C., Parisod, C. \& Gustafsson, A.L. (2010) Climate cooling promoted the expansion and radiation of a threatened group of South American orchids (Epidendroideae: Laeliinae). Biological Journal of the Linnean Society, 100, 597-607.

Antunes, A., Faria, R., Johnson, W.E., Guyomard, R. \& Alexandrino, P. (2006) Life on the edge: the long-term persistence and contrasting spatial genetic structure of distinct brown trout life histories at their ecological limits. Journal of Heredity, 97, 193-205.

Arditti, J. \& Ghani, A.K.A. (2000) Numerical and physical properties of orchid seeds and their biological implications. New Phytologist, 145, 367-421.

Bandelt, H.J., Forster, P. \& Roehl, A. (1999) Median-joining networks for inferring intraspecific phylogenies. Molecular Biology and Evolution, 16, 37-48.

Bateman, R.M., Smith, R.J. \& Fay, M.F. (2008) Morphometric and population genetic analyses elucidate the origin, evolutionary significance and conservation implications of Orchis $\times$ angusticruris (O. purpurea $\times O$. simia), a hybrid orchid new to Britain. Botanical Journal of the Linnean Society, 157, 687-711.

Behling, H. (2002) South and southeast Brazilian grasslands during Late Quaternary times: a synthesis. Palaeogeography, Palaeclimatology, Palaeoecology, 177, 19-27.

Behling, H. \& Negrelle, R.R.B. (2001) Tropical rain forest and climate dynamics of the Atlantic lowland, southern Brazil, during the Late Quaternary. Quaternary Research, 56, 383389.

Bridle, J.R. \& Vines, T.H. (2007) Limits to evolution at range margins: when and why does adaptation fail? Trends in Ecology and Evolution, 22, 140-147.

Burton, R.S. (1997) Genetic evidence for long term persistence of marine invertebrate populations in an ephemeral environment. Evolution, 51, 993-998.

Cabanne, G.S., Santos, F.R. \& Miyaki, C.Y. (2007) Phylogeography of Xiphorhynchus fuscus (Passeriformes, Dendrocolaptidae): vicariance and recent demographic expansion in southern Atlantic forest. Biological Journal of the Linnean Society, 91, 73-84.

Carnaval, A.C., Hickerson, M.J., Haddad, C.F.B., Rodrigues, M.T. \& Moritz, C. (2009) Stability predicts genetic diversity in the Brazilian Atlantic forest hotspot. Science, 323, 785789.

Chung, M.Y., Nason, J.D. \& Chung, M.G. (2005) Spatial genetic structure in populations of the terrestrial orchid Orchis cyclochila (Orchidaceae). Plant Systematics and Evolution, 254, 209-219.

van der Cingel, N.A. (2007) Pollination of orchids by Lepidoptera: outcrossing by long distance transport. Orchid biology, reviews and perspectives, Vol. IX (ed. by K.M. Cameron, J. Arditti and T. Kull), pp. 201-259. The New York Botanical Press, New York.

Cornuet, J.M. \& Luikart, G. (1996) Description and power analysis of two tests for detecting recent population bottlenecks from allele frequency data. Genetics, 144, 2001-2014.

Cosacov, A., Sérsic, A.N., Johnson, L., Sosa, V. \& Cocucci, A.A. (2010) Multiple periglacial refugia in the Patagonian steppe and post-glacial colonization of the Andes: the phylogeography of Calceolaria polyrhiza. Journal of Biogeography, 37, 1463-1477.

Costa, L.P. (2003) The historical bridge between the Amazon and the Atlantic forest of Brazil: a study of molecular phylogeography with small mammals. Journal of Biogeography, 30, 71-86.

Cozzolino, S. \& Widmer, A. (2005) Orchid diversity: an evolutionary consequence of deception? Trends in Ecology and Evolution, 20, 487-494.

Cozzolino, S., Cafasso, D., Pellegrino, G., Musacchio, A. \& Widmer, A. (2003) Fine-scale phylogeographical analysis of Mediterranean Anacamptis palustris (Orchidaceae) populations based on chloroplast minisatellite and microsatellite variation. Molecular Ecology, 12, 2783-2792.

Dieringer, D. \& Schlötterer, C. (2003) Microsatellite analyzer (MSA): a platform independent analysis tool for large microsatellite data sets. Molecular Ecology Notes, 3, 167-169.

Diniz-Filho, J.A.F., Telles, M.P.C., Bonatto, S., Eizirik, E., Freitas, T.R.O., de Marco, P., Santos, F.R., Solé-Cava, A. \& Soares, T.N. (2008) Mapping the evolutionary twilight zone: molecular markers, populations and geography. Journal of Biogeography, 35, 753-763.

Dirienzo, A., Peterson, A.C., Garza, J.C., Valdes, A.M., Slatkin, M. \& Freimer, N.B. (1994) Mutational processes of simplesequence repeat loci in human populations. Proceedings of the National Academy of Sciences USA, 91, 3166-3170.

Duminil, J., Fineschi, S., Hampe, A., Jordano, P., Salvini, D., Vendramin, G.G. \& Petit, R.J. (2007) Can population genetic structure be predicted from life-history traits? The American Naturalist, 169, 662-672.

Eckert, C.G., Samis, K.E. \& Lougheed, S.C. (2008) Genetic variation across species' geographical ranges: the centralmarginal hypothesis and beyond. Molecular Ecology, 17, 1170-1188. 
Ennos, R.A. (1994) Estimating the relative rates of pollen and seed migration among plant populations. Heredity, 72, 250 259.

Evanno, G., Regnaut, S. \& Goudet, J. (2005) Detecting the number of clusters of individuals using the software Structure: a simulation study. Molecular Ecology, 14, 2611-2620.

Excoffier, L. \& Lischer, H.E.L. (2010) Arlequin suite ver 3.5: a new series of programs to perform population genetics analyses under Linux and Windows. Molecular Ecology Resources, 10, 564-567.

Fay, M.F., Bone, R., Cook, P., Kahandawala, I., Greensmith, J., Harris, S., Pedersen, H.Æ., Ingrouille, M.J. \& Lexer, C. (2009) Genetic diversity in Cypripedium calceolus (Orchidaceae) with a focus on northwestern Europe, as revealed by plastid DNA length polymorphisms. Annals of Botany, 104, 517-525.

Ferreira, P.M.A., Müller, S.C., Boldrini, I.I. \& Eggers, L. (2010) Floristic and vegetation structure of a granitic grassland in southern Brazil. Revista Brasileira de Botânica, 33, 21-36.

Fuhro, D. (2006) O sistema Asclepias curassavica L., Epidendrum fulgens Brongn. e Lantana camara L. constitui um complexo mimético, com borboletas como operadores? Um estudo no Parque Estadual de Itapeva, Torres, RS. MSc Thesis, Universidade Federal do Rio Grande do Sul, Porto Alegre, Brazil. Available at: http://hdl.handle.net/10183/8340.

Garza, J.C. \& Williamson, E.G. (2001) Detection of reduction in population size using data from microsatellite loci. Molecular Ecology, 10, 305-318.

Goudet, J. (1995) FSTAT (version 1.2): a computer program to calculate F-statistics. Journal of Heredity, 86, 485-486.

Hágsater, E. \& Soto-Arenas, M.A. (2005) Epidendrum L. Genera Orchidacearum, Vol. 4 (ed. by A.M. Pridgeon, P.J. Cribb, M.W. Chase and F.N. Rasmussen), pp. 236-251, Oxford University Press, Oxford.

Hedrick, P. (2005) A standardized genetic differentiation measure. Evolution, 59, 1633-1638.

Hesp, P.A., Giannini, P.C.F., Martinho, C.T., Silva, G.M. \& Neto, N.E.A. (2009) The Holocene barrier systems of the Santa Catarina coast, southern Brazil. Geology and geomorphology of Holocene coastal barriers of Brazil (ed. by S.R. Dillenburg and P.A. Hesp), pp. 94-133. Springer-Verlag, Berlin.

Hewitt, G.M. (1996) Some genetic consequences of ice ages, and their role in divergence and speciation. Biological Journal of the Linnean Society, 58, 247-276.

Hubisz, M.J., Falush, D., Stephens, M. \& Pritchard, J.K. (2009) Inferring weak population structure with the assistance of sample group information. Molecular Ecology Resources, 9, $1322-1332$.

Jacquemyn, H., Brys, R., Vandepitte, K., Honnay, O. \& Ruiz, I.R. (2006) Fine-scale genetic structure of life history stages in the food deceptive orchid Orchis purpurea. Molecular Ecology, 15, 2801-2808.

Jakob, S.S., Martinez-Meyer, E. \& Blattner, F.R. (2009) Phylogeographic analyses and paleodistribution modeling indicate Pleistocene in situ survival of Hordeum species (Poaceae) in southern Patagonia without genetic or spatial restriction. Molecular Biology and Evolution, 26, 907-923.

Kadereit, J.W., Arafeh, R., Somogyi, G. \& Westberg, E. (2005) Terrestrial growth and marine dispersal? Comparative phylogeography of five coastal plant species at a European scale Taxon, 54, 861-876.

King, M.G., Horning, M.E. \& Roalson, E.H. (2009) Range persistence during the last glacial maximum: Carex macrocephala was not restricted to glacial refugia. Molecular Ecology, 18, 4256-4269.

Kirkpatrick, M. \& Barton, N.H. (1997) Evolution of a species' range. The American Naturalist, 150, 1-23.

Leal, M.G. \& Lorscheitter, M.L. (2007) Plant succession in a forest on the lower northeast slopes of Serra Geral, Rio Grande do Sul, and Holocene palaeoenvironments, southern Brazil. Acta Botanica Brasilica, 21, 1-10.

Ledru, M.P., Salatino, M.L.F., Ceccantini, G., Salatino, A., Pinheiro, F. \& Pintaud, J.C. (2007) Regional assessment of the impact of climatic change on the distribution of a tropical conifer in the lowlands of South America. Diversity and Distributions, 13, 761-771.

Micheneau, C., Duffy, K.J., Smith, R.J., Stevens, L.J., Stout, J.C., Civeyrel, L., Cowan, R.S. \& Fay, M.F. (2010) Plastid microsatellites for the study of genetic variability in the widespread Cephalanthera longifolia, C. damasonium and C. rubra (Neottieae, Orchidaceae), and cross amplification in other Cephalanthera species. Botanical Journal of the Linnean Society, 163, 181-193.

Moreira, A.S.F.P., Fuhro, D. \& Isaias, R.M.S. (2008) Anatomia floral de Epidendrum fulgens Brongn. (Orchidaceae - Epidendroideae) com ênfase no nectário e sua funcionalidade. Revista de Biologia Neotropical, 5, 23-29.

Myers, N., Mittermeier, R.A., Mittermeier, C.G., da Fonseca, G.A.B. \& Kent, J. (2000) Biodiversity hotspots for conservation priorities. Nature, 403, 853-858.

Nei, M. \& Chesser, R.K. (1983) Estimation of fixation indices and gene diversities. Annals of Human Genetics, 47, 253-259.

Nordström, S. \& Hedrén, M. (2009) Genetic diversity and differentiation of allopolyploid Dactylorhiza (Orchidaceae) with particular focus on the D. majalis ssp. traunsteineri/ lapponica complex. Biological Journal of the Linnean Society, 97, 52-67.

van Oosterhout, C., Hutchinson, W.F., Wills, D.P.M. \& Shipley, P. (2004) MICRO-CHECKER: software for identifying and correcting genotyping errors in microsatellite data. Molecular Ecology Notes, 4, 535-538.

Ortiz, M.Á., Tremetsberger, K., Talavera, S., Stuessy, T. \& García-Castaño, J.L. (2007) Population structure of Hypochaeris salzmanniana DC. (Asteraceae), an endemic species to the Atlantic coast on both sides of the Strait of Gibraltar, in relation to Quaternary sea level changes. Molecular Ecology, 16, 541-552.

Palma-Silva, C., Lexer, C., Paggi, G.M., Barbará, T., Bered, F. \& Bodanese-Zanettini, M.H. (2009) Range-wide patterns of nuclear and chloroplast DNA diversity in Vriesea gigantea 
(Bromeliaceae), a neotropical forest species. Heredity, 103, 503-512.

Petit, R.J., El Mousadik, A. \& Pons, O. (1998) Identifying populations for conservation on the basis of genetic markers. Conservation Biology, 12, 844-855.

Petit, R.J., Duminil, J., Fineschi, S., Hampe, A., Salvini, D. \& Vendramin, G.G. (2005) Comparative organization of chloroplast, mitochondrial and nuclear diversity in plant populations. Molecular Ecology, 14, 689-701.

Pinheiro, F., Santos, M.O., Barros, F., Meyer, D., Salatino, A., Souza, A.P. \& Cozzolino, S. (2008a) Isolation and characterization of microsatellite loci in the Brazilian orchid Epidendrum fulgens. Conservation Genetics, 9, 1661-1663.

Pinheiro, F., Santos, M.O., Palma-Silva, C., Barros, F., Meyer, D., Salatino, A., Souza, A.P. \& Cozzolino, S. (2008b) Isolation and characterization of microsatellite loci in Epidendrum puniceoluteum, an endemic orchid from the Atlantic Rainforest. Molecular Ecology Resources, 8, 1114-1116.

Pinheiro, F., Palma-Silva, C., Barros, F., Félix, L.P., Lexer, C., Cozzolino, S. \& Fay, M.F. (2009) Chloroplast microsatellite markers for the Neotropical orchid genus Epidendrum, and cross-amplification in other Laeliinae species (Orchidaceae). Conservation Genetics Resources, 1, 505-511.

Pons, O. \& Petit, R.J. (1996) Measuring and testing genetic differentiation with ordered vs. unordered alleles. Genetics, 144, 1237-1245.

Rambo, B. (1950) A Porta de Torres. Anais Botânicos do Herbário Barbosa Rodrigues, 2, 125-136.

Rambo, B. (1954a) Análise histórica da flora de Porto Alegre. Sellowia, 6, 9-111.

Rambo, B. (1954b) História da flora do litoral riograndense. Sellowia, 6, 112-172.

Raymond, M. \& Rousset, F. (1995) GENEPOP (version 1.2): population genetics software for exact tests and ecumenicism. Journal of Heredity, 86, 248-249.

Ribeiro, R.A., Lemos-Filho, J.P., Ramos, A.C.S. \& Lovato, M.B. (2011) Phylogeography of the endangered rosewood Dalbergia nigra (Fabaceae): insights into the evolutionary history and conservation of the Brazilian Atlantic Forest. Heredity, 106, 46-57.

Salgueiro, F., Felix, D., Caldas, J.F., Margis-Pinheiro, M. \& Margis, R. (2004) Even population differentiation for maternal and biparental gene markers in Eugenia uniflora, a widely distributed species from the Brazilian coastal Atlantic rain forest. Diversity and Distributions, 10, 201-210.

Scarano, F.R. (2002) Structure, function and floristic relationships of plant communities in stressful habitats marginal to the Brazilian Atlantic Rainforest. Annals of Botany, 90, 517-524.

Seeliger, U. (1992) Coastal foredunes of southern Brazil: physiography, habitats, and vegetation. Coastal plant communities of Latin America (ed. by U. Seeliger), pp. 367-381. Academic Press, San Diego, CA.

Souza, C.R.G., Hiruma, S.T., Sallun, A.E.M., Ribeiro, R.R. \& Sobrinho, J.M.A. (2008) "Restinga", conceitos e empregos do termo no Brasil e implicações na legislação ambiental. Instituto Geológico, São Paulo.

Stehlik, I., Schneller, J.J. \& Bachmann, K. (2002) Immigration and in situ glacial survival of the low-alpine Erinus alpinus (Scrophulariaceae). Biological Journal of the Linnean Society, 77, 87-103.

Thomé, M.T.C., Zamudio, K.R., Giovanelli, J.G.R., Haddad, C.F.B., Baldissera, F.A., Jr \& Alexandrino, J. (2010) Phylogeography of endemic toads and post-Pliocene persistence of the Brazilian Atlantic Forest. Molecular Phylogenetics and Evolution, 55, 1018-1031.

Weir, B.S. \& Cockerham, C.C. (1984) Estimating F-statistics for the analysis of population structure. Evolution, 38, 13581370.

Widmer, A. \& Lexer, C. (2001) Glacial refugia: sanctuaries of allelic richness, but not for gene diversity. Trends in Ecology and Evolution, 16, 267-269.

\section{SUPPORTING INFORMATION}

Additional Supporting Information may be found in the online version of this article:

Appendix S1 Overview of the main types of habitats where Epidendrum fulgens can be found.

Appendix S2 Epidendrum fulgens natural growing conditions and flower morphology.

Appendix S3 Magnitude of $\Delta K$ from struCtURE analysis as a function of $K$. 